\title{
References:
}

1. Столяренко Л.Д. Основы психологии. Ростов н/Д, 2003. 672 с.

2. Марютина Т.М., Ермолаев О.Ю. Введение в психофизиологию. Москва, 2002. 400 с.

3. Практический интеллект / Р.Дж. Стернберг, Дж.Б. Форсайт, Дж.Хедланд, Дж.А. Хорвард и др. Спб: Питер, 2002. 272 с.

4. Елисеев О.П. Практикум по психологии личности. СПб: Питер, 2008. 512 c.

5. Айзенк Г.Ю. Проверьте свои интеллектуальные способности. Рига: Виеда. 1992. 171 с.

6. Пальчик А.Б.Эволюционная неврология. СПб: Питер, 2002. $384 \mathrm{c}$.

7. Лурия А.Р. Основы нейропсихологии. М.: Наука, 1975. 374 с.

8. Батаршев А.В. Диагностика черт личности и акцентуаций: Практическое руководство. М. : Психотерапия, 2006. 288 с.

DOI https://doi.org/10.30525/978-9934-588-81-5-2.15

\section{ЗНАЧЕННЯ ВИВЧЕННЯ ВНУТРІШНІХ ХВОРОБ У ФАХОВІЙ ПІДГОТОВЦІ ЛІКАРЯ}

Третяк Н. Г.

кандидат медичних наук, доиент кафедри внутрішньої медицини № 1

Українська медична стоматологічна академія

Штомпель В. Ю.

кандидат медичних наук, викладач

Полтавський базовий медичний коледж

Кудря І. П.

кандидат медичних наук, асистент кафедри внутрішньої медицини № 1 Украӥнська медична стоматологічна академія

Шапошник О. А.

кандидат медичних наук, доиент кафедри внутрішньої медищини № 1 Украӥнська медична стоматологічна академія м. Полтава, Украӥна

Особливу роль у формуванні світогляду лікаря будь-якого фаху відіграє вивчення внутрішніх хвороб, оскільки узагальнює клінічні 
проблеми захворювань органів та акцентує увагу на загальних змінах в організмі хворого.

Курс внутрішніх хвороб $є$ найважливішим етапом в підготовці майбутнього лікаря та займає центральне місце у його фаховій підготовці. Існує безліч тісних зв'язків між терапією і всіма іншими клінічними медичними спеціальностями.

В діагностичному процесі особливу роль відіграє ретельне вивчення анамнезу в комплексній оцінці всіх результатів обстеження, що вимагає від лікаря суворої логіки міркувань, відкриваючи у студентів унікальні можливості формування загального клінічного лікарського мислення в процесі навчання [1, с. 198]. Формування логічного мислення - підгрунтя лікарської майстерності. Мислення лікаря, маючи специфічний об'єкт, проте підкоряється загальним законам, що забезпечують його ефективність - законам логік.

Образне мислення грунтується не тільки й не скільки на аналізі окремих симптомів, скільки на наявному обліку їх зв 'язків, асоціацій 3 іншими ознаками, які піддаються безпосередньому динамічному спостереженню.

Логічне мислення майбутнього лікаря в процесі постановки первинного діагнозу з подальшим його диференціюванням базується на обліку асоціативних співвідношень симптомів та синдромів. Від мистецтва володіння методами диференційного діагнозу залежить кваліфікація лікаря та якість надання медичної допомоги хворим.

Велику роль відіграє інтуїція та образні уявлення фахівця. Це виходить 3 медичного постулату, що захворювання, практично не можна ідентифікувати за описом, тобто визначати за класифікаційною шкалою симптомів.

У досвідченого лікаря, який володіє образним мисленням та інтуїцією, діагностичний пошук на першому місці (уточнювальному) можна розглядати як перцептивне поняття.

Завданнями перцептивних дій $є$ пошук, знаходження, розрізнення, ідентифікація й відображення об'єктивної природи зовнішніх властивостей і відношень предметів з обов'язковою їх якісною і кількісною характеристикою. Важливість цього структурного елемента пояснюється тим, що саме завдання визначають ті предмети та їх властивості, які необхідно виділити, і тим, що завдання детермінують вибір засобів і способів здійснення перцептивних дій. Отримана при цьому інформація повинна носити символьний (багатозначний) і образний характер. Ні у кого вже не викликає особливого сумніву той факт, що інтуїція, досить тісно пов'язана з образним мисленням, відіграє значну 
роль у формулюванні первинних гіпотез правильного діагностичного пошуку [2, с. 78].

Викладання внутрішніх хвороб розглядається в контексті загальних завдань підготовки фахівця з вищою медичною освітою. Звісно ж, що 3 деякою часткою умовності можна виділити кілька груп таких завдань. Першою групою завдань $€$ навчити всіх студентів мислити логічно, показуючи на конкретних прикладах, як слід шукати найбільш раціональний та ефективний шлях до встановлення діагнозу, як правильно оцінювати тяжкість стану хворого і прогноз хвороби, як приймати самостійні рішення в окремих випадках, керуючись загальними принципами. Другою групою завдань потрібно вдосконалити навички розпитування і фізичного дослідження хворого, придбані студентами в курсі пропедевтики внутрішніх хвороб; сформувати вміння встановити психологічний контакт з хворим; прищепити почуття персональної лікарської відповідальності, одночасно розуміння необхідності консультацій і врахування думки колег; створити умови для усвідомлення студентами принципів медичної етики та деонтології; забезпечити міцне засвоєння основ діагностики, лікування і профілактики ряду найбільш поширених захворювань внутрішніх органів $[3$, c. 206].

За час вивчення внутрішніх хвороб студенти засвоюють та інші важливі професійні навички, такі як здатність до встановлення довірчих відносин з пацієнтом, вміння усвідомлено, цілеспрямовано та ефективно отримувати необхідну інформацію в ході бесіди з хворим і при проведенні спеціального обстеження. Навчання спілкуванню між лікарем та хворим $є$ одна із важливих складових вивчення внутрішньої медицини. Спілкування - це складний, багатоплановий процес встановлення і розвитку контактів між людьми, що виникає на основі потреб і спільної діяльності, включає в себе обмін інформацією, сприймання та розуміння іншого. Також, це взаємодія суб'єктів через знакові засоби, викликана потребами спільної діяльності та спрямована на значимі зміни стану, поведінки партнера [4, с. 56].

Сьогодні стало очевидним, що перехід до освіти, орієнтованої на світовий освітній простір передбачає постійне зростання самостійної роботи студентів. Процес навчання не повинен бути процесом передачі знань від викладача до студента. Знання мають бути отримані у процесі активної особистої діяльності студента. Самостійна робота студента із другорядної виходить на рівнозначну з іншими компонентами навчального процесу. Роль викладача лишається так само, як і раніше важливою, але змінюються його функції. Він тепер не є єдиним джерелом первинної інформації, а стає організатором пізнавальної діяльності 
студентів, консультує та орієнтує на різні види самостійної роботи. Ефективність самостійної роботи студента суттєво залежить і від організації контролю за її виконанням з боку педагога. Тому удосконалення методів самостійної роботи та контролю за нею стає актуальною роботою викладача в сучасній вищій школі [1, с. 199].

Більшість практичних занять за методикою організації $є$ клінічними. Вони спрямовані на контроль засвоєння теоретичного матеріалу й формування практичних навичок та вмінь, а також уміння аналізувати й застосовувати отримані знання для вирішення практичних завдань.

Студенти під наглядом викладача працюють в палатах, обстежують хворих. Одним з основних моментів роботи $є$ постановка попереднього діагнозу, призначення плану обстеження і лікування хворого. Даний вид роботи направлений на формування у студентів уміння клінічного мислення, творчої уяви та моделювання тактики лікаря в конкретній клінічній ситуації [4, с. 56].

На жаль, у деяких студентів під час роботи біля ліжка хворого залишаються нерозвиненими «пропедевтичні» мануальні навички, знання яких повинні бути заповнені на старших курсах. Методи навчання на клінічних кафедрах якісно відрізняються від методів, які звичайно використовуються викладачами теоретичних дисциплін. Стиль та особливості мислення формуються протягом усього періоду навчання, однак вираженого професійного відтінку вони набувають на старших курсах. Мислити самостійно, приймати самостійне рішення, обгрунтовувати його, а іноді й доводити свою власну точку зору чи свою думку - основа навчання студента. Студенти 6 курсу залучаються до безпосередньої участі в лікувальному процесі з постійною курацією хворих, участю в щоденних обходах, а потім обов'язковим обговоренням діагнозу з викладачем і аналізом всіх дій, що стосуються реальних хворих $з$ усіма їх діагностичними та лікувальними проблемами, які в даний час знаходяться в терапевтичному відділенні або клініці, де проводяться заняття. Складність ситуації лише привертає увагу студентів, стимулює їх до творчого мислення, підштовхує до пошуку спеціальної літератури, сприяє виникненню бажання реально допомогти хворому.

Під час навчання студенти отримують не тільки теоретичні знання iз захворювань внутрішніх органів, а і навички практичного ведення пацієнтів, які є базовими для подальшого навчання в різних спеціалізаціях.

Таким чином, правильна організація вивчення внутрішніх хвороб у майбутніх лікарів сприяє формуванню клінічного мислення, професі- 
оналізму, компетентності та комунікабельності, що є запорукою успішної фахової діяльності.

\title{
Література:
}

1. Кудря І.П., Шевченко Т.І., Третяк Н.Г., Шапошник О.А. Оптимізація самостійної роботи студентів у світлі інноваційних освітніх технологій при вивченні внутрішньої медицини. Східноукраӥнський медичний журнал. 2020. Т. 8. № 2. С. 195-203.

2. Романцов М.Г., Сологуб Т.В. Педагогические технологии в медицине: учебное пособие. М.: ГЭОТАР-Медиа, 2007. 112 с.

3. Свистунов А.А. Протопопов А.А., Ребров А.П., Пономарева Е.Ю., Волошинова Е.В. Организация учебного процесса в интернатуре по внутренним болезням. Саратовский научномедициинский журнал. 2010. № 1. С. 206-208.

4. Воробйов Є.О., Шевченко Т.I., Сорокіна С.І., Кудря I.П., Шапошник О.А. Шляхи оптимізації проведення лікарської виробничої практики 3 внутрішньої медицини у студентів 4 курсу медичних вузів в умовах Болонського процесу. Медична освіта. 2011. № 3. С. 55-58.

DOI https://doi.org/10.30525/978-9934-588-81-5-2.16

\section{КЛЕТОЧНЫЙ СОСТАВ ПЕРИФЕРИИ ОЧАГА ВОСПАЛЕНИЯ ПРИ ХРОНИЧЕСКОМ ВОСПАЛЕНИИ НА ФОНЕ ВВЕДЕНИЯ ГЛЮКОЗАМИНИЛМУРАМИЛДИПЕПТИДА}

\author{
Шевченко А. Н. \\ доктор медицинских наук, профессор,
} профессор кафедры патологической физиологии имени Д. Е. Альперна

Харьковский национальный медицинский университет

\section{Бибиченко В. А.}

кандидат медицинских наук, ассистент кафедры патологической физиологии имени Д. Е. Альперна Харьковский национальный медицинский университет

$$
\text { 2. Харьков, Украина }
$$

Лечение воспалительных процессов глюкокортикоидными гормонами, другими иммунодепрессантами создает реальную угрозу для перехода воспаления в хроническую форму. 